Revista Brasil. Bot., V.30, n.4, p.587-597, out.-dez. 2007

\title{
Mountain biodiversity in Brazil
}

\author{
GUSTAVO MARTINELLI ${ }^{1}$
}

(received: June 17, 2007; accepted: October 19, 2007)

\begin{abstract}
Mountain biodiversity in Brazil). The high species richness and diversity found in tropical montane habitats are often related to: 1) an effect of climatic and geological history on biotic evolution; 2) the various environmental impacts on species adaptation mechanisms; and 3) the continuous dispersal of fauna and flora in time. However, little is known about how these factors shaped species richness in Brazilian mountains. Official documents on biodiversity in Brazil make no explicit reference to mountains, even though there is a mountain work programme of the Convention on Biological Diversity, which Brazil is a signatory of. This paper discusses the importance of mountain ecosystems in Brazil to show the urgent need to include mountain biodiversity in the national agenda of biodiversity research and conservation.
\end{abstract}

Key words - Brazilian mountains, Convention on Biological Diversity, mountain biodiversity, nomenclature of neotropical mountains

RESUMO - (Biodiversidade de montanhas no Brasil). Os altos graus de riqueza e diversidade de espécies encontrados em montanhas tropicais são freqüentemente atribuídos a: 1) ao efeito da história climática e geológica sobre a evolução biótica; 2) aos vários impactos ambientais sobre os mecanismos de adaptação biótica; e 3) à contínua dispersão da fauna e flora no tempo. Entretanto, pouco se sabe acerca de como estes fatores afetaram a riqueza de espécies em montanhas brasileiras. Documentos oficiais disponíveis sobre a biodiversidade brasileira não fazem referência explícita à biodiversidade de montanhas no país, muito embora desde 2002 este tema tenha sido considerado ponto focal na Convenção para a Diversidade Biológica, da qual o Brasil é signatário. O objetivo do presente trabalho é caracterizar a importância dos ecossistemas de montanhas do Brasil e mostrar a necessidade de incluir a biodiversidade de montanhas nas agendas nacionais de conservação e pesquisa científica.

Palavras-chave - biodiversidade de montanhas, Convenção da Diversidade Biológica, montanhas brasileiras, nomenclatura de montanhas neotropicais

\section{Introduction}

No universal definition of mountains exists; many different terms are in use, reflecting diverse disciplines, traditions and objectives. The one adopted by the Convention on Biological Diversity describes mountains as follows: "Mountains are characterized by distinctive abiotic, biotic, social, cultural, economic and spiritual values. Structurally, these areas tend to have a combination of the following physical and biological characteristics: elevation, high or slope terrain, diverse climates, a relatively high composition of endemic and native species, and degrees of fragility and remoteness. Functionally, these are water towers of the world and can serve as a refuge for many populations. Mountain regions also tend to be inclusive of lowland communities which depend on the provision of goods and services, such as water, energy, food, timber, wildlife, game recreation and spiritual value" (UNEP/CBD/AHTEGMB 2003).

1. Instituto de Pesquisas Jardim Botânico do Rio de Janeiro, Rua Pacheco Leão 930, 22460-030 Rio de Janeiro, RJ, Brazil. gmartine@jbrj.gov.br
Mountain ecosystems occur in all climatic zones of the globe and cover approximately $25 \%$ of the planet's surface. Whilst there are some extensive high chains, mountains are often isolated from one another, and some form visually striking islands, emerging from the surrounding lowlands. Mountains are topographically and geologically highly diversified, which is a causal factor in their high biological diversity (Spehn \& Körner 2005). About $12 \%$ of the world's population lives in mountains, which results in moderate to high perturbation regimes.

Biodiversity is a good indicator of mountain ecosystem integrity. A functionally diverse plant cover provides soil stability, reduces erosion and the occurrence of landslides, and contributes to maintaining hydrological properties (Körner 2002). Healthy mountain ecosystems provide harvestable products, form the basis for protection of soil, watersheds and water quality, are an increasingly sought after target for tourism and recreation, and have a rich natural and cultural heritage (Körner \& Ohsawa 2005). To reflect the importance of mountain biodiversity to mankind the Eighth Conference of the Parties of the Convention on Biological Diversity (CBD) proposed a Mountain Work Programme (MWP) in 2002 
to reduce global, regional and local loss of mountain biodiversity. Some key features of the MWP include: (i) concentration of biodiversity hotspots in mountain areas, ecosystem diversity, species richness and number of endemic and threatened species; (ii) the fragility of mountain ecosystems and species and their vulnerability to man-made and natural disturbances, particularly in relation to land-use and climatic changes; (iii) the interconnectedness between highlands and lowlands, especially as regards water and soil, and (iv) the high level of cultural diversity, including the key role of indigenous and local communities in conservation and management of biological diversity (UNEP/CDB/ AHTEG-MB 2003).

This paper is an overview of mountain research in Brazil - which is often hidden or fragmented - that lists mountain sites and locations that are threatened and/or understudied. Further, I propose the creation of a national programme on mountain biodiversity, so as to protect and produce knowledge about the great biological richness of these habitats.

\section{Mountain biodiversity}

Mountain ecosystems are typically diverse and rich in species, particularly in the tropics (Chaverri-Polini 1998, Sarmiento 2002). This may be attributed to three main factors that have acted at different time scales: biotic evolution in response to climatic and geological history; species adaptations to environmental constraints; and biotic exchanges with the surrounding lowlands (Sarmiento 2002). Thus, both plant migration and in situ evolution are essential processes to understand tropical mountain species richness. The high altitude areas of the Itatiaia plateau (Rio de Janeiro, Brazil) provide an interesting example of this combination of causal factors: (1) it became a temperate vegetation island surrounded a tropical rain forest when conditions became warmer after the last glaciation (see Ribeiro et al. 2007, in this issue); (2) it has many interesting cases of adaptive histories, such as that of cacti and bromeliads that locally perform $\mathrm{C}_{3}$ photosynthesis, although they belong to genera that typically display crassulacean acid metabolism (Scarano et al. 2001); and (3) some of the species first establish on rocks and subsequently create the necessary substrate for other species to establish, including those originated from the surrounding rain forest (Scarano 2002).

Over the years, there have been various accounts published on the flora and vegetation, and the fauna of several mountain ecosystems (e.g., Hedberg 1969, Weber,
1972, Van Steenis 1974, Loffler 1984, Kitayama 1996). Despite this, there is still a major need for more inventories, particularly in Brazil (but see in this issue Caiafa \& Silva 2007, Conceição et al. 2007, Felfili et al. 2007) and for basic and applied research in view of managing such ecosystems.

Studies on biodiversity in isolated mountains (including high mountain tops) are amenable to applying the theory of island biogeography (MacArthur \& Wilson 1967). For instance, Barbará et al. (2007) have shown that disjoint distribution patterns and gene flow result in high levels of differentiation for bromeliad populations in inselbergs. Restrictions to gene flow and reduced connectivity between individuals of predominantly out-crossing species suggest that mountain vegetation can indeed be comparable to oceanic islands in this respect.

The isolated nature of many such habitats has also favoured evolutionary studies on endemisms, speciation and adaptation (Chaverri-Polini 1998, Schönswetter et al. 2005, Hughes \& Eastwood 2006), as well as global-scale comparative studies (Porembski et al. 1998, Porembski \& Barthlott 2000). Moreover, the biodiversity-ecosystem function paradigm (see overview on this topic in Srivastava \& Vellend 2005, Scarano 2007) is highly relevant to mountain biodiversity research (e.g., Quarterman et al. 1993, Hopper et al. 1997, Shure 1999, Porembski \& Barthlott 2000).

Despite the obvious relevance of research on mountain habitats for ecological theory and biodiversity science as a whole, there are still major hurdles to be overcome by mountain research. Habitat heterogeneity and landscape complexity, for instance, remain as challenging features for such studies (Escudero 1996). They often impose methodological difficulties and peculiarities that result in difficulties for comparative studies between sites, or even for the establishment of replicates within a given study site (see Caiafa \& Silva 2007 and Ribeiro et al. 2007 in this issue).

\section{Neotropical mountains}

Following early explorers in the high mountains of South America (e.g., Humboldt's expedition in 1819, Engler 1910, Mildbraed 1922), the first synthetic works were published on the Andean "páramos" and "punas" by Vuilleumier (1970), Monasterio (1980), and on the Venezuelan "tepuis" by Huber \& Alarcón (1988), Berry et al. (1995), and by Huber (1995). A recent volume covered tropical inselbergs (Porembski \& Barthlott 2000). Some of the Neotropical mountains are well known for their high diversity and endemisms, such as some parts of the 
Andes (Moraes \& Beck 1992, Clark 1995, Gentry 1995, Gradstein 1995, Rangel 1995), some montane forests in Central and South America (Chaverri-Polini 1998) and the "tepuis" of the Guiana Shield (see Gröger \& Huber 2007, in this issue). However, few comparative studies are available and little is known about ecosystem function and processes in these mountains and their habitats.

The biological characteristics of neotropical mountains are very much influenced by past geological events (e.g., Pleistocene glaciations), as well as present day climatic and edaphic factors (Chaverri-Polini 1998). The occurrence of a cold, temperate climate within a tropical zone is often the basis for the very insular nature of vegetation in such areas, as well as that of the fauna. Air humidity and soil conditions are largely variable among mountains. For instance, in dry, arid mountains, soils are often highly saline, whereas in humid mountains soil acidity and aluminum content tend to be higher (Chaverri-Polini 1998). Therefore, it is not surprising that diverse vegetation types and plant communities occur (table 1, Udvardy 1975, Chaverri-Polini 1998). Thus, the suggestion of Huber \& Riina (1997) that an effort should be made to achieve a single classification system for the neotropics is still in order.

Climate, geomorphology and soil characteristics turn mountain habitats into particularly sensitive environments to human use. The time required for natural regeneration and susceptibility to soil erosion are some of the major constraints (Chaverri-Polini 1998). Human activities may take place over large areas, and include agriculture, foraging by domestic animals, introduction and cultivation of exotic species (e.g., Pinus, Eucalyptus, Cupressus, Brachiaria, Mellinis), deforestation, burning, illegal extraction of plant species, mining and predatory tourism (e.g., Cavelier \& Etter 1995, ChaverriPolini \& Herrera 1996).

\section{Brazilian mountains}

The official documents on biodiversity in Brazil make no reference to mountain biodiversity, although the theme has been considered a focal point of the Convention on Biological Diversity (of which Brazil is a signatory) since 2002. For instance, many of the

Table 1. Regional names of the main vegetation types and plant community physiognomies in Latin American mountains. Altitudes are informed, but precision is difficult due to the immense variation from country to country. Modified from Chaverri-Polini (1998), by adding information from the following sources: Graf (1981), Giulietti et al. (1987), Dezzeo \& Huber (1995), Doumenge et al. (1995), Kapelle (1996), Martinelli (1996), Chaverri-Polini \& Herrera (1996), AlmeidaLeñero (1997), Chaverri-Polini \& Cleef (1997), Huber \& Riina (1997), Muñoz \& Bonacic (2006), Altmann (2006).

\begin{tabular}{ll}
\hline Vegetation type & \multicolumn{1}{c}{ Description } \\
\hline "Páramo" & $\begin{array}{l}\text { Top of mountains (3,000-4,500 m a.s.1.); canopy } \\
\text { height up to 2m; typical plant groups: Poaceae, } \\
\text { Cyperaceae, Asteraceae, Rosaceae, Ericaceae, } \\
\text { Apiaceae, Swallenochloa, Espeletia. }\end{array}$ \\
& High part of the Andes (above 3,400 m a.s.l.); herbs \\
& (Poaceae, Cyperaceae) and some shrubs; climate \\
"Puna" & cold and relatively dry. \\
Vegetação das montanhas vulcânicas (> 3,800 \\
m.a.s.l.) \\
"Campos Alpinos (zacatonal)" \\
Mountains of the Atlantic Forest (1,200-2,900 m \\
a.s.l.); shrubs and herbs: Asteraceae, Melastomataceae, \\
Orchidaceae Bromeliaceae, Trilepsis \\
Cerrado mountains (1,000-2,000 m a.s.l.); shrubs \\
"Campos Rupestres" \\
and herbs: Asteraceae, Xyridaceae, Velloziaceae, \\
Cyperaceae, Melastomataceae \\
Amazônia"
\end{tabular}
Countries (biomes)

Costa Rica, Panama, Colombia, Venezuela, Ecuador, Peru.

Peru, Bolivia, Chile, Argentina.

Mexico, Guatemala

Brazil (Atlantic forest)

Brazil ("Cerrado")

Brazil ("Amazonia") 
continuation

\begin{tabular}{lll}
\hline Vegetation type & Description & Countries (biomes) \\
\hline
\end{tabular}

“Tepuis”

Peat Bog (no regional name; it is a variation of "Bofedal")

"Bofedal"

"Arrayan"

"Queñoa"

Andean Montane Forest

Andean fringe Forest (chaparral)

"Yungas"

Cloud forest

Montane forest

Shady Montane Forest

Conifer forest

Pinus and oak forest

Oak forest
Mountain (1,400-3,000 m a.s.1.) vegetation complex: forests, shrubby, herbaceous and savannic forms; Poaceae and Bromeliaceae

Azonal vegetation (3,500-4,900 m a.s.1.) in flooded and poorly drained areas (peat bog): Cyperaceae, Juncaceae, Ericaceae, Sphagnum

Azonal vegetation (3,000-5,500 $\mathrm{m}$ a.s.1.) in flooded areas (marshland), characterized by the presence of hard cushion plants; Plantago, Distichia, Cyperaceae

Ecotone between the "páramos" and the Andean forests (various altitudes) characterized by Ericaceae shrubs.

Dwarf upper montane forest, with small trees and treelets with distorted trunks. Altitude: from 4,000 m a.s.1.; abundance of epiphytes on Polylepis.

Lower montane, evergreen forest; very humid; many epiphytes; common plants: Weinmannia, Podocarpus, Polylepis, Ericaceae and Araliaceae. Altitudinal range is variable.

Highland vegetation between the "páramos" and the Andean forests, characterized by coriaceous leaves and heavily thorned dwarf shrubs. Altitudinal range is variable.

Xeromorphic, shrubby, latifoliate (400-3,000 m a.s.1.). Sub-tropical montane deciduous and evergreen forests which flank the eastern slopes and valleys of the Andes

Various forests, occurring along several altitude ranges. Humid and cloudy throughout the year. Lauraceae, Myrtaceae, Melastomataceae, Ericaceae and many epiphytes.

Forest-type vegetation, which varies according to the region where it is located.

Altitudinal forest with intermediate height; $(1,800$ 2,800 m a.s.l.) humid; many epiphytes, Podocarpaceae, Araliaceae, Alnus, Brunellia and Weinmannia.

Intermediate altitude (1,000-3,000 m a.s.1.): Pinus, Juniper, Abies and Cupressus.

Intermediate altitude (900-1,600 m a.s.1.): Quercus and Pinus.

Forest with predominance of trees of the genus Quercus, Chletra, Ilex, Styrax, Lauraceae, Araliaceae and many epiphytes (1,600-2,800 $\mathrm{m}$ a.s.1.)
Venezuela and Brazil

Costa Rica, Colombia, Peru, Bolivia, Chile, Argentina, Venezuela

Bolívia, Chile, Peru

Costa Rica, Colômbia, Chile

Bolivia, Colombia, Peru, Chile

Colombia, Ecuador, Peru, Bolívia, and other countries of the Andean range

Ecuador and other countries of Andean range)

Peru, Bolivia, Argentina.

Porto Rico (low altitudes), El Salvador, Costa Rica, Colombia, Venezuela, Bolivia, Brazil.

All countries

Venezuela

Mexico, Guatemala, Honduras, El Salvador, Nicarágua, Chile, Venezuela

Mexico, Guatemala, Honduras (in low altitudes), Nicaragua.

Mexico, Guatemala, Honduras, Nicarágua, Colômbia. 
priority areas for biological inventories and creation of conservation units for various Brazilian biomes, designated by using general criteria mostly related to their forest remnants and/or scenic beauty status (MMA 2002), are montane sites. The importance and ecological singularity of mountains by itself has not been considered.

Existing mountain areas are treated as part of other biomes or biogeographic regions (e.g., MMA 1998, 2000, 2004, 2006; table 2). This is perhaps the legacy of past focus on other biomes and conservation priorities in lowland ecosystems, where large-scale land use has been concentrated. However, it is important to realize the importance of mountain systems, both ecologically and economically and allocate resources for their study and management for long-term provision of ecosystem services.

The highest mountain ranges in Brazil are found in the Amazon (states of Amapá, Amazonas, Pará and Roraima) and the Atlantic forest biomes ("Serra da Mantiqueira"; e.g. Benites et al. 2007, Ribeiro et al. 2007). However, most mountain biodiversity research in Brazil is concentrated in elevations within the "cerrado" biome ("campos rupestres"; e.g., Coelho et al. 2007, Figueira \& Del Sarto 2007, Medina \& Fernandes 2007, Velten
\& Garcia 2007), and in the "campos de altitude" of the Atlantic Rainforest biome (Martinelli 1996, Porembski et al. 1998, Safford 1999, Safford \& Martinelli 2000, Caiafa \& Silva 2007, Ribeiro et al. 2007). This pattern repeats itself in the present special issue: none of the studies published here are set in the Brazilian Amazon, and most concentrate within the "cerrado" and the Atlantic forest biomes. This must be urgently reversed, given the high number of rock outcrops and/or high altitude areas within the Amazon and the "caatinga" biomes (table 2).

\section{Conservation needs of mountainous areas in Brazil}

Although most Brazilian mountain chains and inselbergs are at least partly covered by conservation units (MMA 2002, Machado et al. 2004, Rylands \& Brandon 2005), most such protected areas still lack specific conservation and management plans that would take into account the peculiarities of mountain environments. Thus, various mountain regions, particularly those within the biomes Atlantic forest, "cerrado" and "caatinga", are largely degraded or threatened. The main threats are common to other mountain habitats in the neotropics:

Table 2. Brazilian mountains with partial or total absence of biological information in each major biome: $(*)$ areas selected based on the document "Biodiversidade Brasileira: Avaliação e Identificação de Áreas e Ações Prioritárias para a Conservação, Utilização Sustentável e Repartição de Benefícios da Biodiversidade Brasileira - Vegetação" (MMA 2002); (**) author's personnal observations. States: $\mathrm{PA}=$ Pará; $\mathrm{AP}=$ Amapá; $\mathrm{AM}=$ Amazonas; $\mathrm{RR}=$ Roraima; $\mathrm{AC}=\mathrm{Acre}$; $\mathrm{PI}=$ Piauí; $\mathrm{CE}=$ Ceará; RN = Rio Grande do Norte; $\mathrm{PE}=$ Pernambuco; $\mathrm{PB}=$ Paraíba; $\mathrm{BA}=$ Bahia; ES = Espírito Santo; MG = Minas Gerais; RJ = Rio de Janeiro; MT = Mato Grosso; TO = Tocantins; GO = Goiás; SC = Santa Catarina; RS = Rio Grande do Sul. (CU = conservation unit; $\mathrm{H}=$ highly important $; \mathrm{E}=$ extremely important; $0=$ no information available. Regional terminology has been maintained. Equivalents in English to Portuguese terminology are: "serra" = mountain range; "alto" = high elevation; "pico" = peak; "monte" = mount; "morro" = mountain; "rio" = river; "pedra" or "rochedo" = stone or rock, "chapada" = mountain plain.)

\begin{tabular}{llll}
\hline Biome/site/location & State & Priority actions & Importance \\
\hline Amazon & & & \\
"Serra do Divisor"** & AC & Inventory & H \\
"Alto Rio Juruá"* & AC & Restoration, inventory, managament \\
"Tepui Surucucu"* & RR & Inventory, creation of CU, management \\
"Tepui Serra da Ufaranda"* & RR & Inventory, creation of CU & H \\
"Monte Roraima"* & RR & Restoration, inventory, creation of CU \\
"Pico da Neblina and adjacent mountains"* & AM & Restoration, inventory, managament \\
"Rio Içana"* & AM & Restoration, inventory, managament \\
"Serra Igarapé-Pégua"* & AM & Restoration, inventory, managament \\
"Tepui Serra do Araçá"* & AM & Inventory & E \\
"Pico 31 de Março"** & AM & Inventory & E \\
"Morro dos Seis Lagos"* & AM & Inventory & E \\
"Inselbergs Rio Curicuriare"** & AM & Inventory, creation of CU & E \\
"Serra Imeri"* & AM & Inventory, creation of CU
\end{tabular}


continuation

\begin{tabular}{|c|c|c|c|}
\hline Biome/site/location & State & Priority actions & Importance \\
\hline "Serra de Tapirapecó"* & $\mathrm{AM}$ & Inventory & $\mathrm{E}$ \\
\hline "Alto Jari e Amapari"* & PA/AP & Inventory, creation of CU, management & $\mathrm{E}$ \\
\hline "Inselbergs da Serra do Tumucumaque"** & PA/AP & Inventory & $\mathrm{E}$ \\
\hline "Serra dos Carajás"* & PA & Inventory, creation of $\mathrm{CU}$, management & $\mathrm{E}$ \\
\hline “Serra de Maicuru”* & PA & Inventory, creation of CU, management & $\mathrm{H}$ \\
\hline "Inselbergs Rio Parú Doeste"* & PA & Inventory, creation of CU & $\mathrm{E}$ \\
\hline "Granitoides do Rio Mapuera"* & PA & Inventory, creation of $\mathrm{CU}$ & $\mathrm{H}$ \\
\hline \multicolumn{4}{|l|}{ "Caatinga" } \\
\hline "Serra do Estevão"* & PI & Inventory & $\mathrm{E}$ \\
\hline "Serra das Confusões"** & PI & Inventory & $\mathrm{E}$ \\
\hline "Serra Vermelha"** & PI & Inventory & $\mathrm{E}$ \\
\hline "Serra das Almas"** & $\mathrm{PI} / \mathrm{CE}$ & Inventory & $\mathrm{H}$ \\
\hline "Serra das Flores"** & $\mathrm{CE}$ & Inventory & $\mathrm{E}$ \\
\hline "Pico do Cabugi"* & $\mathrm{CE}$ & Inventory & 0 \\
\hline "Serra de Santana"* & $\mathrm{CE}$ & Inventory & 0 \\
\hline "Rochedo de Serra Caiada"** & $\mathrm{CE}$ & Inventory & 0 \\
\hline "Serra de Porto Alegre"** & $\mathrm{CE}$ & Inventory & 0 \\
\hline "Serra de Santa Catarina"* & $\mathrm{RN}$ & Inventory & $\mathrm{H}$ \\
\hline "Monte Horebe"* & $\mathrm{PB} / \mathrm{CE}$ & Inventory & $\mathrm{H}$ \\
\hline "Buique"** & PE & Inventory & $\mathrm{H}$ \\
\hline "Chapada do Araripe"* & PE & Inventory & $\mathrm{E}$ \\
\hline "Serra do Ororubá"*** & $\mathrm{PE}$ & Inventory & $\mathrm{E}$ \\
\hline "Inselbergs of Triunfo"*** & $\mathrm{PE}$ & Inventory & $\mathrm{E}$ \\
\hline "Inselbergs of Vale de Ipojuca"** & $\mathrm{PE}$ & Inventory, creation of $\mathrm{CU}$ & $\mathrm{E}$ \\
\hline “Inselbergs of Quipapá”** & $\mathrm{PE}$ & Inventory, creation of $\mathrm{CU}$ & $\mathrm{E}$ \\
\hline "Inselbergs of Brejo da Madre de Deus"** & $\mathrm{PE}$ & Inventory, creation of $\mathrm{CU}$ & $\mathrm{E}$ \\
\hline "Serra Talhada"* & $\mathrm{PE}$ & Inventory & $\mathrm{E}$ \\
\hline "Serra do Açuruá"** & BA & Inventory & $\mathrm{E}$ \\
\hline "Chapada Diamantina"* & BA & Finalize inventory & $\mathrm{E}$ \\
\hline "Calcarium outcrops at the margin of Rio São & MG & Inventory & $\mathrm{E}$ \\
\hline \multicolumn{4}{|l|}{ Francisco in the vicinities of Januária”* } \\
\hline \multicolumn{4}{|l|}{ “Cerrado” } \\
\hline "Serra do Cachimbo"** & MT & Finalize inventory & $\mathrm{E}$ \\
\hline "Serra da Petrovina"** & MT & Inventory, creation of CU & $\mathrm{E}$ \\
\hline "Afloramentos Sitio Santa Felina"** & MT & Inventory & $\mathrm{H}$ \\
\hline "Serra dos Caiabis"** & MT & Inventory & $\mathrm{E}$ \\
\hline "Serra das Araras e Serra Azul"** & MT & Inventory & $\mathrm{E}$ \\
\hline "Chapada dos Guimarães"* & MT & Inventory & $\mathrm{E}$ \\
\hline "Serra Ricardo Franco"** & MT & Inventory & $\mathrm{E}$ \\
\hline “Lageados de arenito de Rondonópolis”*** & MT & Inventory, creation of CU & $\mathrm{E}$ \\
\hline "Serra em Miracema do Tocantins"** & TO & Inventário & $\mathrm{H}$ \\
\hline "Serra do Lajeado"** & TO & Inventory, creation of $\mathrm{CU}$ & $\mathrm{E}$ \\
\hline "Alto do Araguainha"** & GO/MT & Inventory, creation of CU & $\mathrm{E}$ \\
\hline "Serra Geral de Goiás"** & $\mathrm{GO} / \mathrm{BA}$ & Inventory & $\mathrm{E}$ \\
\hline "Serra da Mesa"** & $\mathrm{GO}$ & Inventory & $\mathrm{E}$ \\
\hline "Serra do Pirineus"** & GO & Inventory, creation of CU & $\mathrm{E}$ \\
\hline "Chapada dos Veadeiros"** & $\mathrm{GO}$ & Finalize inventory & $\mathrm{H}$ \\
\hline "Pedra Menina"** & MG & Finalize inventory & $\mathrm{E}$ \\
\hline "Serra da Bodoquena"** & MS & Inventory & $\mathrm{E}$ \\
\hline
\end{tabular}


continuation

\begin{tabular}{|c|c|c|c|}
\hline Biome/site/location & State & Priority actions & Importance \\
\hline \multicolumn{4}{|l|}{ Atlantic forest } \\
\hline "Pico do Jabre"** & PB & Inventory, creation of $\mathrm{CU}$ & $\mathrm{H}$ \\
\hline "Inselbergs of Jaqueira"** & PE & Inventory, creation of CU & $\mathrm{E}$ \\
\hline "Inselbergs of Serra da Naceia"** & $\mathrm{AL}$ & Inventory, creation of $\mathrm{CU}$ & $\mathrm{E}$ \\
\hline "Serra Lisa"** & $\mathrm{AL}$ & Inventory, creation of CU & $\mathrm{E}$ \\
\hline "Ipirá / Serra do Orobó”** & BA & Inventory & $\mathrm{E}$ \\
\hline "Pico do Barbado"** & BA & Inventory (transition area) & $\mathrm{H}$ \\
\hline "Inselbergs de Itamaraju”** & BA & Inventory, creation of CU & $\mathrm{E}$ \\
\hline "Serra da Lontra"** & BA & Inventory & $\mathrm{E}$ \\
\hline "Serra da Panelinha"** & BA & Inventory & $\mathrm{E}$ \\
\hline "Serra da Jibóia"** & $\mathrm{BA}$ & Inventory & $\mathrm{E}$ \\
\hline "Serra do Ramalho"** & BA & Inventory & $\mathrm{H}$ \\
\hline "Pedra Azul"* & $\mathrm{MG} / \mathrm{BA}$ & Inventory & $\mathrm{E}$ \\
\hline “Inselbergs Teófilo Otoni”** & $\mathrm{MG} / \mathrm{BA}$ & Inventory, creation of $\mathrm{CU}$ & $\mathrm{E}$ \\
\hline "Serra do Brigadeiro"** & MG & Inventory & $\mathrm{E}$ \\
\hline "Pedra Dourada"** & MG & Inventory & $\mathrm{H}$ \\
\hline "Serra de Ibitipoca"** & MG & Inventory & $\mathrm{E}$ \\
\hline "Serra de Aiuruoca"** & MG & Inventory & $\mathrm{E}$ \\
\hline "Inselbergs de Pancas"** & $\mathrm{ES}$ & Inventory, creation of $\mathrm{CU}$ & $\mathrm{E}$ \\
\hline "Inselbergs Santa Teresa"** & $\mathrm{ES}$ & Inventory & $\mathrm{H}$ \\
\hline "Inselbergs da Região Serrana ES"** & ES & Inventory & $\mathrm{H}$ \\
\hline "Inselbergs Cariacica-Vitória"** & ES & Inventory & $\mathrm{E}$ \\
\hline "Inselbergs Cachoeiro do Itapemirim-Alegre"** & ES & Inventory, creation of $\mathrm{CU}$ & $\mathrm{E}$ \\
\hline "Inselbergs Forno Grande"** & ES & Inventory & $\mathrm{E}$ \\
\hline "Serra das Torres"** & ES & Inventory & $\mathrm{E}$ \\
\hline "Pico do Frade de Angra"** & RJ & Inventory & $\mathrm{E}$ \\
\hline "Pedra do Desengano"* & RJ & Inventory & $\mathrm{E}$ \\
\hline "Inselbergs do NE do RJ"** & RJ & Inventory & $\mathrm{E}$ \\
\hline “Serra dos Três Picos"** & RJ & Inventory & $\mathrm{E}$ \\
\hline "Inselbergs de Morro do Coco"** & RJ & Inventory & $\mathrm{E}$ \\
\hline "Inselbergs de Bom Jardim”** & RJ & Inventory & $\mathrm{E}$ \\
\hline "Serra da Bocaina"* & $\mathrm{SP} / \mathrm{RJ}$ & Inventory & $\mathrm{E}$ \\
\hline "Pico do Corcovado"** & SP & Inventory & 0 \\
\hline "Pedra da Mina, Cupim de Boi e Três Estados"** & SP & Inventory & 0 \\
\hline "Pico Itaguaré e Marins"** & SP & Inventory & $\mathrm{E}$ \\
\hline "Maciço da Pedra do Baú”** & SP & Inventory & $\mathrm{E}$ \\
\hline "Conjunto de Serras Marumbi”** & PR & Inventory & $\mathrm{E}$ \\
\hline "Serra Capivari Grande"** & PR & Inventory & $\mathrm{E}$ \\
\hline "Serra Ibitiraquire"** & PR & Inventory & $\mathrm{E}$ \\
\hline "Serra da Graciosa"** & PR & Inventory & $\mathrm{E}$ \\
\hline "Serra da Farinha Seca"** & PR & Inventory & $\mathrm{E}$ \\
\hline "Serra do Iquererim”** & PR & Inventory & $\mathrm{E}$ \\
\hline "Serra do Leão"* & PR & Inventory & $\mathrm{E}$ \\
\hline "Serra dos Castelhanos"** & PR & Inventory & $\mathrm{E}$ \\
\hline “Serra de Araçatuba"** & PR & Inventori & $\mathrm{E}$ \\
\hline "Serra de São Luiz do Purunã"** & PR & Inventory & $\mathrm{E}$ \\
\hline "Serra da Anta Gorda"* & $\mathrm{SC}$ & Inventory & $\mathrm{E}$ \\
\hline "Serra do Rio do Rastro"* & $\mathrm{SC}$ & Inventory & $\mathrm{E}$ \\
\hline "Serra Furada"* & $\mathrm{SC}$ & Inventory & $\mathrm{E}$ \\
\hline "Serra do Tabuleiro"** & $\mathrm{SC}$ & Inventory & $\mathrm{E}$ \\
\hline "Serra Geral"** & $\mathrm{SC} / \mathrm{RS}$ & Inventory & $\mathrm{H}$ \\
\hline "Campos de Cima da Serra"** & RS & Inventory & $\mathrm{E}$ \\
\hline "Aparados da Serra"* & RS & Inventory & \\
\hline
\end{tabular}


sensitivity of soils to anthropogenic activities, promoting erosion and instability; removal of buffer vegetation in surrounding areas facilitating invasibility; low competitive capacity of the local flora versus invaders; fire and burning; intense extraction of attractive species of the flora that are often endemic or rare; mining (granite, gneiss, sandstone); urban expansion; high altitude agriculture (e.g., coffee cultivation in some parts of the state of Espírito Santo may reach up to 1,200 m a.s.l., at the foot of the rock outcrops); installation of energy transmission and communication facilities; difficulties regarding law enforcement and protection, monitoring, restoration, and ex-situ conservation; high susceptibility to climate change.

Conservation planning should account for the distinct communities and life zones within the mountain range, particularly in regard to altitude. Regional and national borders might require bilateral partnerships for entire ecosystem conservation and integrity, since mountains are often used as geopolitical limits between countries, states and municipalities (World Bank 2002). Other official priorities are sustainable use of the biodiversity, establishment of biological corridors, reafforestation of deforested mountains (CCAD/CCAB$\mathrm{AP} / \mathrm{FAO}$ 1997) and promotion of natural regeneration in areas used for pasture (World Bank 2002).
In order to include mountain ecosystems in the Brazilian agenda of conservation of biological diversity and to promote the necessary actions for preserving mountain regions, I have suggested ten actions in a report to the Secretary to Forestry and Biodiversity of the Brazilian Ministry for Environment - SBF/MMA (Martinelli 2003): (1) to establish a National Programme for Mountain Research and Conservation, in a partnership between the Brazilian Ministry for Environment and Ministry for Science and Technology (see table 3 for a list of ongoing international programmes); (2) to promote the articulation of multidisciplinary work groups to integrate scientific knowledge available on Brazilian mountains, organizing a database with open access; (3) to promote biological inventories in unknown or underexplored areas (see table 2); (4) to explicitly include mountain ecosystems in the national policy for biodiversity; (5) to create a research and conservation fund for mountain biodiversity, with emphasis in biological inventories; (6) to prepare an action plan for mountain conservation and sustainable development; (7) to set as a priority the restoration of degraded buffer areas, with particular emphasis in the Atlantic forest biome; (8) to foster an integrated management plant to reconcile integrity of hydrographic basins, urban

Table 3. Examples of ongoing international programs concerned with a global evaluation of richness of mountain biota its causes and its changes in time. Note that most such initiatives focus on mountain ecosystems of Europe, North America and Asia.

Programs and Agencies
Alpine Convention
Centre for Mountain Studies
"Consorcio para el Desarrollo de la Ecoregion Andina" (CONDESAN)

Food and Agriculture Organization (FAO)

Global Mountain Biodiversity Assessment (GMBA), which is part of "Diversitas" (an international agency for the development of biodiversity research on mountains)

International Centre for Integrated Mountain Development (ICIMOD)

International Partnership for Sustainable Development in Mountain Regions

International Mountain Society

International Union of Forest Research Organizations (IUFRO)

Mountain Research Initiative (MRI)

Mountain Forum

Mountain Partnership

World Conservation Monitoring Centre (WCMC)
Host country

Innsbruck, Austria

Perth, United Kingdon

Peru (including over 85 institutions and organization of the Andean countries of Argentina, Bolivia, Colombia, Chile and Ecuador)

Rome, Italy

Basel, Switzerland

Kathmandu, Nepal

Hosted by FAO (Rome, Italy)

Berne, Switzerland

Vienna, Austria

Zurich, Switzerland

Kathmandu, Nepal

Rome, Italy

Cambridge, United Kingdom 
expansion and agriculture in mountain, identifying the best practices to avoid degradation and to guarantee stability and maintenance of ecological services; (9) to revise and analyse the network of protected areas in mountain regions; and finally (10) to promote training and formation of personnel involved with mountain habitats.

Considering both the evidences of human impacts on Brazilian mountain and the insufficiency of current knowledge available of ecological systems, it seems necessary and urgent to establish a national program aiming to understand and protect their complexity and functioning. This issue is directly related to at least two other topics already included in the Brazilian biodiversity agenda: sustainable forestry and water resources. A national mountain biodiversity program might integrate and further incentive ongoing efforts of institutions and scientists, such as those reported in this special issue.

Acknowledgements - I thank Laszlo Nágy and Masresha Fetene who revised and made substantial contributions to this paper; Fabio R. Scarano for encouragement and linguistic advice; Miguel d'Ávila de Moraes for assistance with data and vivid discussions about the topic; and Bráulio F. S. Dias and Paulo Y. Kageyama for debates about the idea of creating a national program on mountain biodiversity.

\section{References}

ALMEIDA-LEÑERO, L. 1997. Vegetación, fitogeografia y paleoecologia del zacatonal alpino y bosques montanos de la región central de México. Ph.D. thesis. Amsterdam University, Amsterdam.

ALTMANN, S.H. 2006. Caracterización y classificación de las comunidades de vegetación del fundo Santa Helena, Nuncaqua, Región de O’Higgins, Chile. Chloris Chilensis 9:6-11.

BARBARÁ, T., MARTINELLI, G., FAY, M.F., MAYO, S.J. \& LEXER, C. 2007. Population differentiation and species cohesion in two closely related plants adapted to neotropical high-altitude "inselbergs" Alcantarea imperialis and Alcantarea geniculata (Bromeliaceae). Molecular Ecology 16:1981-1992.

BENITES, V.M., SIMAS, F.N.B., SCHAEFER, C.E.G.R, SANTOS, H.G. \& MENDONÇA, B.A.F. 2007. Soils associated to rock outcrops in the highlands of Serras da Mantiqueira and Espinhaço, southeastern Brazil. Revista Brasileira de Botânica 30:569-577.

BERRY, P.E., HUBER, O. \& HOLST, B.K. 1995. Floristic Analysis and phytogeography. In Flora of the Venezuelan Guayanas (P.E. Berry, B.K. Holst \& K. Yatskievych, eds.). Missouri Botanical Garden Press, St. Louis, p. 161-191.
CAIAFA, A.N. \& SILVA, A.F. 2007. Structural analysis of the vegetation on a highland granitic rock outcrop in southeast Brazil. Revista Brasileira de Botânica 30:657664.

CAVELIER, J. \& ETTER, A. 1995. Deforestation of montane forest in Colombia as a result of ilegal plantation of opium. In Tropical montane cloud florests. (L.S. Hamilton, J.O. Juvik \& F.N. Scatena, eds.), Springer, New York, p.541-550.

CCAD/CCAB-AP/FAO. 1997. Critérios e indicadores para la ordenación forestal sostenible en Centroamérica. Report of expert meeting, 20-24 January 1997, Tegucigalpa, Honduras. Consejo Centroamericano de Ambiente y Desarrollo, Consejo Centroamericano de Bosques y Areas Protegidas, Food and Agriculture Organization, Rome.

CHAVERRI-POLINI, A. 1998. Mountains, biodiversity and conservation. Unasylva 195:22-33.

CHAVERRI-POLINI, A. \& CLEEF, A.M. 1997. Las comunidades vegetacionales em los páramos de los macizos del Chirripó y Buenavista, cordillera de Talamanca, Costa Rica. Revista Forestal Centroamericana 17:44-49.

CHAVERRI-POLINI, A. \& HERRERA, B. 1996. Critérios e indicadores para el manejo forestal sostenible de bosques de altura en Centroamérica. Consultants report. Food and Agriculture Organization, Comisión Centroamericana de Ambiente y Desarrollo y Consejo Centroamericano de Bosques y Areas Protegidas, San Jose.

CLARK, L.G. 1995. Diversity and distribution of the Andean woody bamboos. In Biodiversity and conservation of neotropical montane forests, proceedings (S.P. Churchill, H. Balslev, E. Forero \& J.L. Luteyn, eds). New York Botanical Garden, New York, p.501-512.

COELHO, F.F., CAPELO, C.D.L., NEVES, A.C.O. \& FIGUEIRA, J.E.C. 2007. Vegetative propagation strategies of four rupestrian species of Leiothrix (Eriocaulaceae). Revista Brasileira de Botânica 30:687-694.

CONCEIÇÃO, A.A., PIRANI, J.R. \& MEIRELLES, S.T. 2007. Floristics, structure and soil of insular vegetation in four quartzite-sandstone outcrops of Chapada Diamantina, Northeast Brazil. Revista Brasileira de Botânica 30:641-655.

DEZZEO, N. \& HUBER, O. 1995. Tipos de bosques sobre el cerro Duida, Guayana Venezolana. In Biodiversity and conservation of neotropical montane forests, proceedings (S.P. Churchill, H. Balslev, E. Forero \& J.L. Luteyn, eds). New York Botanical Garden, New York, p.149-158.

DOUMENGE, C., GILMOUR, D., PÉREZ, M.R. \& BLOCKHUS, J. 1995. Tropical montane cloud forests: conservation status and management issues. In Tropical montane cloud florests (L.S. Hamilton, J.O. Juvik \& F.N. Scatena, eds.), Springer, New York, p.24-37.

ENGLER, A. 1910. Die Pflanzenwelt Afrikas. Engelmann, Leipzig. 
ESCUDERO, A. 1996. Community patterns on exposed cliffs in a Mediterranean calcareous mountain. Vegetatio 125:99-110.

FELFILI, J.M., NASCIMENTO, A.R.T., FAGG, C.W. \& MEIRELLES, E.M. 2007. Floristic composition and community structure of a seasonally deciduous forest on limestone outcrops in Central Brazil. Revista Brasileira de Botânica 30:611-621.

FIGUEIRA, J.E.C \& DEL SARTO, M.C.L. 2007. Clonal growth and dispersal potential of Leiothrix flagellaris (Eriocaulaceae) in the rocky grasslands of Southeastern Brazil. Revista Brasileira de Botânica 30:679-686.

GENTRY, A.H. 1995. Patterns of diversity and floristic composition in neotropical montane forest of the tropical Andes. In Biodiversity and conservation of neotropical montane forests, proceedings (S.P. Churchill, H. Balslev, E. Forero \& J.L. Luteyn, eds). New York Botanical Garden, New York, p.321-334.

GIULIETTI, A.M., MENEZES, N.L., PIRANI, J.R., MEGURO, M. \& WANDERLEY, M.G.L. 1987. Flora da Serra do Cipó: caracterização e lista de espécies. Boletim de Botânica da Universidade de São Paulo 9:1-151.

GRADSTEIN, S.R. 1995. Diversity of Hepaticae and Anthoceratoe in montane forests of the tropical Andes. In Biodiversity and conservation of neotropical montane forests, proceedings. (S.P. Churchill, H.Balslev, E. Forero \& J.L. Luteyn, eds). New York Botanical Garden, New York, p.321-334.

GRAF, K. 1981. Palinological investigation of two postglacial peatbogs near the boundary of Bolivia and Peru. Journal of Biogeography 8:353-368.

GRÖGER, A. \& HUBER, O. 2007. Rock outcrop habitats in the Venezuelan Guayana lowlands: their main vegetation types and floristic components. Revista Brasileira de Botânica 30:599-609.

HEDBERG, O. 1969. Evolution and speciation in a tropical high mountain flora. Biological Journal of the Linnean Society 1:135-148.

HOPPER, S.D., BROWN, A.P. \& MARCHANT, N.G. 1997. Plants of Western Australian granite outcrops. Journal of the Royal Society of Western Australia 80:141-158.

HUBER, O. 1995. Vegetation. In Flora of the Venezuelan Guayana. (J.A. Steyermark, P.E. Berry \& B.K. Holst, eds.). Missouri Botanical Garden, St. Louis, p.97-160.

HUBER, O. \& ALARCÓN, C. 1988. Mapa de vegetación de Venezuela. Ministerio del Ambiente y de los Recursos Naturales Renovables (MARNR), The Nature Conservancy, Fundación Bioma, Caracas.

HUBER, O. \& RIINA, R. 1997. Glosario fitoecológico de las Américas. v.1. United Nations Educational, Scientific and Cultural Organization - UNESCO, Caracas.

HUGHES, C.E. \& EASTWOOD, R.J. 2006. Island radiation on a continental scale: exceptional rates of plant diversification after uplift of the Andes. Proceedings of the National Academy of Sciences 103:10334-10339.
HUMBOLDT, A. 1819. Relation historique du Voyage aux regions equinoxiales du Nouveau Continent, ait en 1799-1804 par A. de Humboldt et A. Bompland, Maze, Paris. v.2.

KAPELLE, M. 1996. Los bosques de robles (Quercus) en la Cordillera de Talamanca, Costa Rica, INBio, Amsterdan University, Heredia.

KITAYAMA, K. 1996. Patterns of species diversity on an oceanic versus a continental island mountain: a hypothesis on species diversification. Journal of Vegetation Science 7:879-888.

KÖRNER, C. 2002. Mountain biodiversity: its causes and functions. In Mountain Biodiversity: a global assessment. (C. Körner \& E.M. Spehn, eds.). Parthenon, London, p.3-6.

KÖRNER, C. \& OHSAWA, M. 2005. Mountain systems. In Ecosystems and human well-being: current State and trends. Findings of the Conditions and Trends Working Group of the Millennium Ecosystem Assessment (R. Hassan, R. Scholes \& N. Ash, eds.). Island Press, Washington DC, p.681-716.

LOFFLER, H. 1984. The importance of mountains for animal distribution, species speciation, and faunistic evolution. Mountain Research and Development 4:299-304.

MACARTHUR, R.H. \& WILSON, E.O. 1967. The theory of island biogeography. Princeton University Press, Princeton.

MACHADO, R.B., AGUIAR, L.M.S., RAMOS NETO, M.B., HASS, A. \& AQUINO, F.B. 2004. Atlas de Conservação da Natureza: unidades federais. Metalivros, São Paulo.

MARTINELLI, G. 1996. Campos de Altitude. Editora Index, Rio de Janeiro.

MARTINELLI, G. 2003. Relatório de participação da reunião do grupo de especialistas em montanhas (Ad Hoc Technical Expert Group on Mountain Biodiveristy AHTEG-MB) realizada em Roma, Itália para a Secretaria de Biodiversidade e Florestas do Ministério do Meio Ambiente. Ministério do Meio Ambiente, Brasília.

MEDINA, B.M.O. \& FERNANDES, G.W. 2007. Natural regeneration potential of rupestrian fields soils' in Serra do Cipó, Brazil. Revista Brasileira de Botânica 30:665678.

MILDBRAED, J. 1922. Wissenschaftliche Ergebnisse der zweiten deutschen Zentral-Afrika-Expedition 1910-1011. Band II: Botanik. Klinkhardt \& Biermann, Leipzig.

MMA. 1998. Primeiro relatório nacional para a Convenção da Diversidade Biológica. Ministério do Meio Ambiente, Brasília.

MMA. 2000. Política Nacional de Biodiversidade: roteiro de consulta para elaboração de uma proposta. Ministério do Meio Ambiente, Brasília.

MMA. 2002. Biodiversidade Brasileira: Avaliação e Identificação de Áreas e Ações Prioritárias para Conservação, Utilização Sustentável e Repartição de Benefícios da Biodiversidade Brasileira. Ministério do Meio Ambiente, Brasília. 
MMA. 2004. Segundo relatório nacional para a Convenção da Diversidade Biológica. Ministério do Meio Ambiente, Brasília.

MMA. 2006. Diretrizes e prioridades do Plano de Ação para implementação da Política Nacional da Biodiversidade. Ministério do Meio Ambiente, Brasília.

MONASTERIO, M. 1980. Las formaciones vegetais de los Páramos de Venezuela. In Estudios Ecológicos en los Páramos Andinos (M. Monasterio, ed.). Ediciones de la Universidade de Los Andes, Merida, p.93-158.

MORAES, M. \& BECK, S. 1992. Diversidad floristica de Bolivia. In Conservación de la diversidad biológica em Bolívia. La Paz, Centro de datos para la conservación - Bolivia, United States Agency for Internacional Development - USAID/Bolívia, La Paz, p.73-111.

MUÑOZ, A.E. \& BONACIC, C. 2006. Vegetación. Gayana Botanica 63:75-92.

POREMBSKI, S. \& BARTHLOTT, W. 2000. Preface. In Inselbergs - Biotic Diversity of Isolated Rock Outcrops in Tropical and Temperate Regions (S. Porembski \& W. Barthlott, eds.). Springer, Heidelberg, p.5-9.

POREMBSKI, S., MARTINELLI, G., OHLEMÜLLER, R. \& BARTHLOTT, W. 1998. Diversity and ecology of saxicolous vegetation mats on inselbergs in the Brazilian Atlantic rainforest. Diversity and Distributions 4:107119.

QUARTERMAN, E., BURBANCK, M.P. \& SHURE, D.J. 1993. Rock outcrops communities: limestone, sandstone, and granite. In Biodiversity of southeastern United States: upland terrestrial communities (W.H. Martin, S.G. Boyce \& A.C. Echternacht, eds.). Wiley, New York, p.35-86.

RANGEL, J.O. 1995. La diversidad florística em el espacio andino de Colombia. In Biodiversity and conservation of neotropical montane forests, proceedings (S.P. Churchill, H. Balslev, E. Forero \& J.L. Luteyn, eds). New York Botanical Garden, New York, p.187-205.

RIBEIRO, K.T., MEDINA, B.M.O. \& SCARANO, F.R. 2007. Species composition and biogeographic relations of the rock outcrop flora on the high plateau of Itatiaia, SE-Brazil. Revista Brasileira de Botânica 30:623-639.

RYLANDS, A.B. \& BRANDON, K. 2005. Unidades de conservação brasileiras. Megadiversidade 1:27-35.

SAFFORD, H.D. 1999. Brazilian páramos: Introduction to the physical environment and vegetation of the campos de altitude. Journal of Biogeography 26:693-712.

SAFFORD, H.D. \& MARTINELLI, G. 2000. Southeast Brazil. In Inselbergs: biotic diversity of isolated rock outcrops in the tropics. (W. Barthlott \& S. Porembski, eds.). Ecological Studies. Springer-Verlag, Berlin, 146, p.339-389.

SARMIENTO, F.O. 2002. Human drivers of landscape change: treelines dynamics in neotropical montology. Ecotropicos 15:129-146.
SCARANO, F.R. 2002. Structure, function and floristic relationships of plant communities in stressful habitats marginal to the Brazilian Atlantic forest. Annals of Botany 90:517-524.

SCARANO, F.R. 2007. Perspectives on biodiversity science in Brazil. Scientia Agricola 64:439-447.

SCARANO, F.R., DUARTE, H.M., RIBEIRO, K.T., RODRIGUES, P.J.F.P., BARCELLOS, E.M.B., FRANCO, A., BRULFERT, J., DELEÉNS, E. \& LÜTTGE, U. 2001. Four sites of contrasting environmental stress in southeastern Brazil: relations of species, life form diversity, and geographic distribution to ecophysiological parameters. Botanical Journal of the Linnean Society 136:345-364.

SCHONSWETTER, P., STEHLIK, I., HOLDEREGGER, R. \& TRIBSCH, A. 2005. Molecular evidence for glacial refugia of mountain plants in European Alps. Molecular Ecology 14:3547-3555.

SHURE, D.J. 1999. Granitic outcrops of the southeastern United States. In Savannas, barrens, and rock outcrop plant communities of North America (R.C. Anderson, J.S. Fralish \& J.M. Baskin, eds.) Cambridge University Press, Cambridge, p.99-118.

SPEHN, E. \& KÖRNER, C. 2005. Global Mountain Biodiversity Assessment (GMBA): A Global Diversitas Network. Abstract of poster presentation at the Eighth meeting of the Subsidiary Body on Scientific, Technical and Technological Advice of the Convention on Biological Diversity. United Nations Environment Programme, Montreal.

SRIVASTAVA, D.S. \& VELLEND, M. 2005. Biodiversityecosystem function research: is it relevant to conservation? Annual Review of Ecology, Evolution and Systematics 36:267-294.

UDVARDY, M.D.F. 1975. A classification of biogeographical provinces of the world. IUCN Occasional Paper 18. International Union for Conservation of Nature, Geneve.

UNEP/CBD/AHTEG-MB. 2003. Programme of work on mountain biological diversity. United Nations Environmental Program, Convention of Biological Diversity, Ad Hoc Technical Expert Group on Mountain Biodiversity. United Nations Environment Programme, Montreal.

VAN STEENIS, C.G.G.J. 1974. The mountain flora of Java. New Phytologist 73:220-621

VELTEN, S.B. \& GARCIA, Q.S. 2007. Variation between three Eremanthus species in their ability to form a seed bank. Revista Brasileira de Botânica 30:713-719.

VUILLEUMIER, F. 1970. Insular biogeography in continental regions. III. The northern Andes of South America. American Naturalist 104:373-388.

WEBER, W.A. 1972. Rocky mountain flora. Taxon 21:702-703. WORLD BANK. 2002. Conservation of Biodiversity in Mountain Ecosystems - At Glance. Special Paper. World Bank, Washington, DC. 